\title{
V.V. Klochko
}

D.K. Zabolotny Institute of Microbiology and Virology, National Academy of Sciences of Ukraine, 154 Zabolotny St., Kyiv 03143, Ukraine

\section{ECOLOGY, SYSTEMATICS AND ANTIBIOTIC ACTIVITY OF PSEUDOMONAS BATUMICI AND ALTEROMONAS MACLEODII IN CONNECTION WITH ANALYSIS OF THEIR GENOME STRUCTURE}

\begin{abstract}
New data about ecology, systematics and synthesis of biologically active substances of the type strain Pseudomonas batumici UCM-321 producing the antibiotic batumin, highly effective against staphylococci, and of Alteromonas macleodii strains, as representatives of marine species widely inhabiting the world ocean, was obtained based on a complex analysis of their biological properties and genomic structure.

Analysis of taxonomic data indicated that P. batumici is a novel species. Illumina $\mathrm{Hi}$ Seq sequencing of the chromosomal DNA enabled to obtain the complete genome sequence of P. batumici UCM B-321. Its DNA contained 127 contigs of the total length of 6608172 bp. Batumin biosynthesis operon was identified as $77 \mathrm{kbp}$ operon containing in total 28 protein coding genes. This operon sequence was significantly less GC-rich and the program SeqWord Genomic Island Sniffer predicted a horizontal acquisition of this region. The closes relatives of UCM-321 were P. gingeri and P. protegens; both have no batumin operon in their genomes. HLPC-analysis of the culture broth has shown the presence of batumin in P. batumici broth and no any similar substances in P. gingeri culture medium.

The phenotypic, chemotaxonomic and genetic peculiarities of 5 deep-water strains of A. macleodii (isolated from a depth of 1000-3500 m) and 5 strains of the same species isolated from the surface layer have been studied. Electron microscopy has shown that the deep strains'cells were, on average, two times longer $(2.1 \pm 0.2 \times 0.7 \pm 0.1 \mu \mathrm{m})$ than the surface strains $(1.1 \pm 0.1 \times 0.6 \pm 0.1 \mu \mathrm{m})$. Using fatty acid analysis the deep and surface isolates were clearly separated into two clusters. The distinctions between them were also found in different lectin binding capacity, which was probably determined by the structure of their extracellular polysaccharide matrix. Analysis of the PCR results with the primers to repeated nucleotide sequences revealed a higher level of genetic polymorphism in surface strains in comparison to the deep-water isolates. The described peculiarities probably reflect the specific conditions in which A. macleodii strains live on the surface or in the depth of the World Ocean.

K e y w o rds: Pseudomonas batumici, antibiotic batumin, Alteromonas macleodii, systematics, genomic structure.
\end{abstract}

Analysis of bacterial genome is one of the important and necessary elements of research in all areas of modern fundamental and applied microbiology. To a full extent it is relevant for the Pseudomonas genus which covers one of the ecologically most significant groups of bacteria with a remarkable degree of genomic diversity and ecological adaptability [1]. To the present time the complete genome sequence was established for 14 Pseudomonas species (data present in Genbank). A considerable progress was also achieved in the study of marine proteobacteria.

The two named groups of microorganisms were studied at the antibiotics department of Zabolotny Institute of Microbiology and Virology (National 
Academy of Sciences of Ukraine) during the last decade. Isolation, polyphasic taxonomic analysis and description of new species of pseudomonads and Alteromonas-like marine bacteria and their antibiotic activity were the main results of this work. The genome analysis was included in the arsenal of methods used, which allowed to establish the connection between some genetic and biological features of the studied microorganisms, their ecology and antibiotic producing activity.

In this article we consider the new data obtained in this area using two objects as examples - Pseudomonas batumici strain producing the polyketyde antibiotic batumin highly effective against staphylococci and Alteromonas macleodii strains, representatives of marine species widely inhabiting the world ocean.

Strains of Pseudomonas batumici were isolated during an investigation of diversity and antibiotic activity of pseudomonads from different natural habitats. Four heterotrophic, oxidase positive, Gram-negative rods, motile by means of few polar flagellae, were isolated from soil samples collected on the Black Sea coast of Caucasus (moist subtropical region) [9].

The results of $16 \mathrm{~S}$ rRNA gene sequence analysis have shown that Pseudomonas batumici UCM B-321 strain formes a separate branch within the genus Pseudomonas and has $98 \%$ of $16 \mathrm{~S}$ rRNA gene sequence similarity with evolutionally most related species $P$. gingeri and $P$. baetica (Fig. 1) [11].

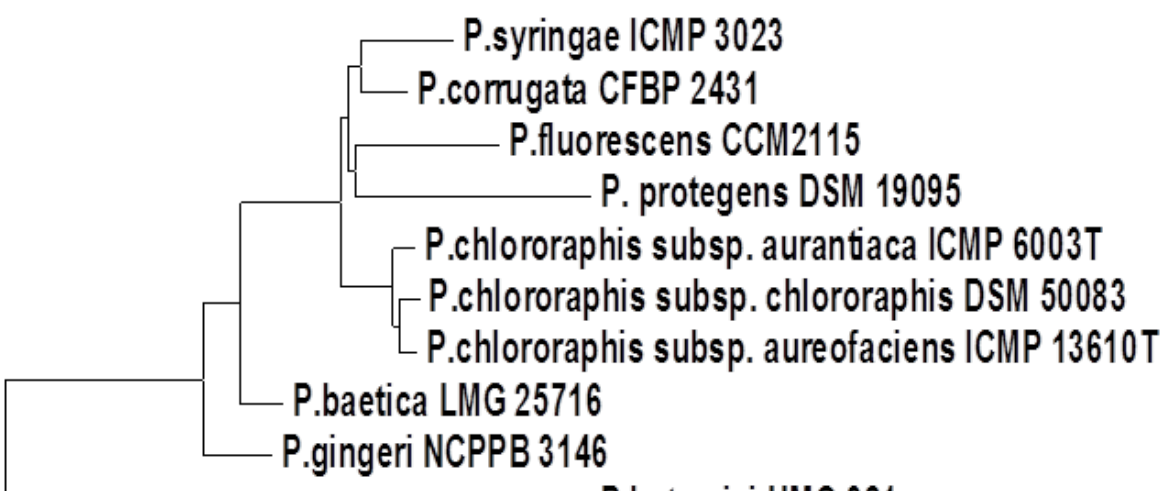

P.batumici UMC-321

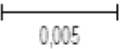

Fig. 1. Phylogenetic position of Pseudomonas batumici UCM B-321 within the genus Pseudomonas based on 16S rRNA gene sequences

The differences between the mentioned species were determined by polyphasic taxonomic analysis along with identification of some enzymes, pigments production ability, spectra of assimilated carbon sources, the fatty acid profiles, antagonistic activity and synthesis of antistaphylococcal antibiotic batumin. Analysis of taxonomic data indicated that $P$. batumici represents a novel species [9].

Illumina Hi-Seq sequencing of the chromosomal DNA enabled to obtain the complete genome sequence of $P$. batumici UCM B-321 ${ }^{\mathrm{T}}$ (Fig. 2). These and supplementary data were deposited at the National Center for Biotechnology 
Information (NCBI) under the accession no. JXDG00000000, BioProject PRJNA270768 and BioSample SAMN03273282. The DNA contained 127 contigs of the total length of $6608172 \mathrm{bp}$ [13].

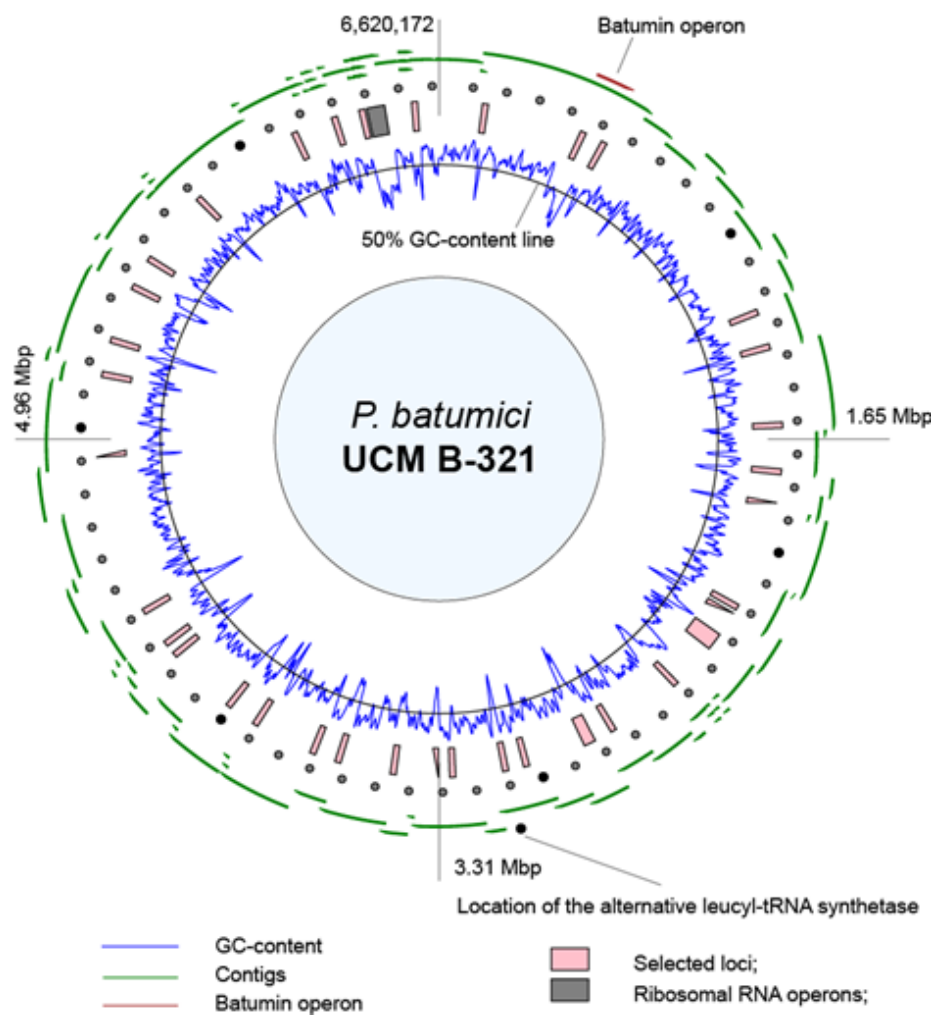

Fig. 2. Atlas of the concatenated contigs of Pseudomonas batumici UCM B-321 shows the locations of predicted genomic islands

The average GC content of $P$. batumici UCM B-321 genome constitutes $61.78 \%$. In the locus covering the batumin operon, the GC content is $<50 \%$. The batumin biosynthesis operon was identified in the center of the large contig 3. Surprisingly the identified $77 \mathrm{kbp}$ long operon contains in total 28 protein coding genes. This operon sequence is significantly less GC-rich (50\% against $64 \%$ in average) than the whole genome sequence and the program SeqWord Genomic Island Sniffer predicted horizontal acquisition of this region [6].

The availability of the whole genome sequence of UCM-321 allowed precise identification of its phylogenetic position among other sequenced Pseudomonas. The closes relatives of UCM-321 were identified as $P$. gingeri NCPPB 3146 and P. protegens CHA0; both have no batumin operon in their genomes. HLPC-analysis of cultural broth showed the prepense of batumin and its minor derivate descarbamoyl batumin in $P$. batumici broth and no any similar substances in $P$. gingeri cultural medium (Fig. 3).

The highest similarity to batumin operon was observed for gene operons encoding bacillaen biosynthesis in Bacillus [6, 7]. During many years of intensive study the attention was fixed on antibiotic batumin, its high and selective activity against staphylococci, its biosynthesis, chemical structure, perspectives of medical use $[2,12,16]$. Batumin synthesis in fermenter occurs in the process of culture growth and its maximal value is achieved after $50-55$ hours. Antibiotic yield comprises $175-180 \mathrm{mg} / \mathrm{l}$ and depends on intensity of aeration [10]. 


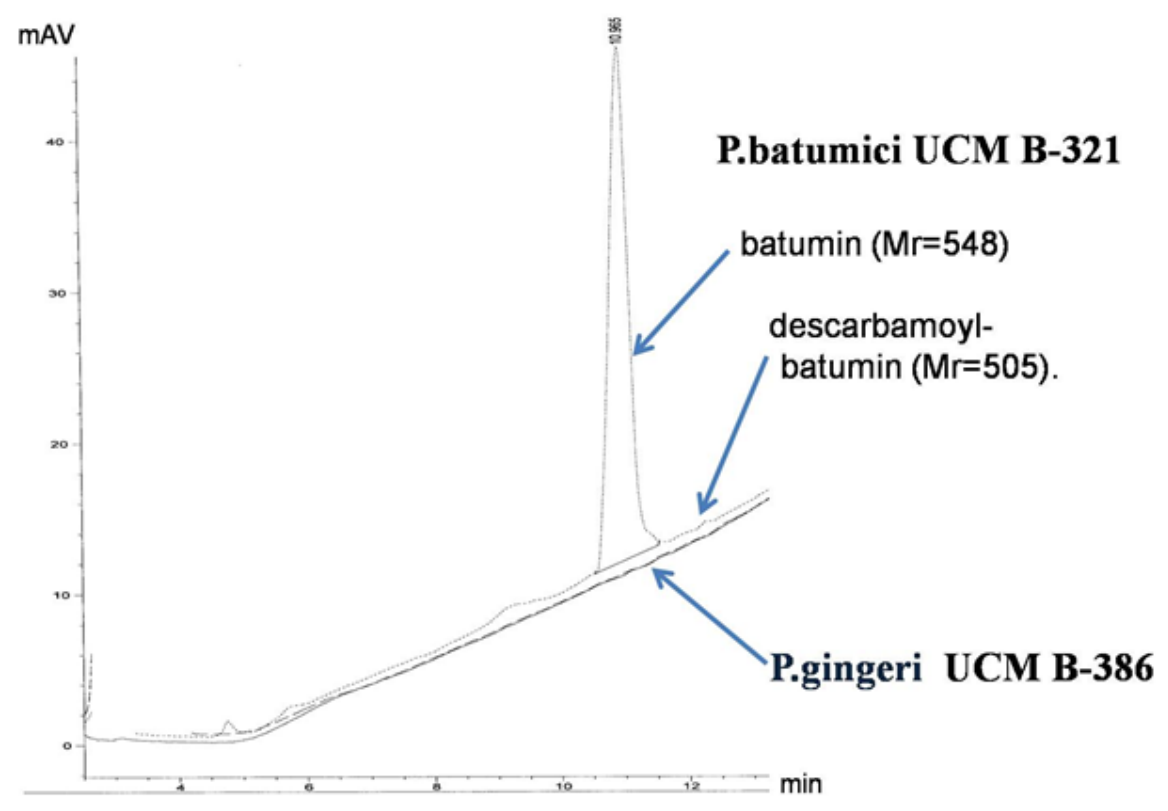

Fig. 3. Determination and identification of culture medium components by LC/MC

Batumin (Fig. 4) was highly active against all studied strains belonging to 10 species of Staphylococcus genus (minimal inhibitory concentration - 0.25$0.5 \mu \mathrm{g} / \mathrm{ml}$ ); it showed a moderate activity against enterobacteria of Salmonella, Bordetella, Escherichia, Klebsiella genera (MIC 8-64 $\mu \mathrm{g} / \mathrm{ml}$ ) and practically did not inhibit any strains of micrococci, streptococci, sporeforming bacteria including Clostridium sporogenes (MIC $256 \mu \mathrm{g} / \mathrm{ml}$ or higher). Strains of yeasts and microscopic fungi Candida tropicalis, C. utilis, C. albicans, Saccharomyces cerevisiae and Aspergillus niger were resistant to batumin.<smiles></smiles>

Fig. 4. Chemical structure of antibiotic batumin

It was shown that the unique batumin antimicrobial effect depends on the presence of double bonds, $\mathrm{CONH}_{2}-, \mathrm{COOH}-$ and $\mathrm{OH}$-groups. Replacement or modification of each of these groups reduced the activity against Staphylococcus and qualitatively changed the antimicrobial spectrum of the antibiotic [8].

At the same time, batumin may target a broader range of aminoacyl tRNA synthetases, including leucyl-tRNA synthetase. Paralogues of diverse leucinetRNA synthetases in the genome of $P$. batumici indicat that this protein might be the prime target of batumin. It appears plausible that the leucyl-tRNA 
synthetase and the batumin operon were acquired by horizontal gene transfer from the same unknown Gram-positive bacterium [13].

The simultaneous $P$. batumici growth and antibiotic biosynthesis and this molecule's capacity to optical isomerisation allow us to suppose that batumin plays a certain role in metabolism of the producing strain. So it is interesting to study not only the ecological role of batumin (which is probably the instrument of competition with other rhizosphere microorganisms), but its other functions in metabolism and survival of this species.

Studies of Alteromonas macleodii - the next object of our experiments concern one of the most widespread heterotrophic marine bacteria found in the North Sea as well as marine waters in tropical and moderate latitudes, inhabiting surface and deep waters [3]. A. macleodii was also detected in the Black Sea during isolation of Alteromonas-like proteobacteria from the Black Sea water [15]. This species was widely studied by scientists of different countries within the framework of the "Global Ocean Sampling project" devoted to fundamental study of genetic biodiversity of marine microbial groups and finding out their role in the natural ecological processes.

Data on the biogeography of $A$. macleodii indicated that there were two different ecotypes from the surface and deep sea waters. These ecotypes were differentiated according to the results of molecular-genetic analysis of A. macleodii strains. It was observed that the size of internal transcribing spacer (ITS) between genes of $16 \mathrm{~S}$ and $23 \mathrm{~S}$ rRNA [15] and the nucleotide sequences of 16S rRNA, gyrB, rpoB genes and several other genes were different for the two ecotypes $[4,15]$. The complete genome sequence of the deep-sea strain A. macleodii DSM 17117 [5] revealed the connection between the genome loci and the biochemical peculiarities and ecological features of these bacteria.

We studied the $A$. macleodii strains isolated from different geographical locations: five strains from sea-surface water samples (D7, D12 were from the Andaman Sea; MED64 was from the Aegean Sea; 621 was from the Atlantic Ocean near the British shore; 29-06 was from the Black Sea) and other five strains from deep water samples: U4, U8, UM4b from the Ionian Sea $(3,500$ $\mathrm{m})$; Adriatic1, Adriatic2 from the Adriatic Sea $(1,000 \mathrm{~m})$. The strains were kindly supplied by Prof. Francisco Rodriguez-Valera (Universidad Miguel Hernandez, Spain); strain 29-06 was isolated from surface water of the Black Sea by O. Onyshchenko (Zabolotny Institute of Microbiology and Virology NASU, Ukraine).

We studied new phenotypic and genetic peculiarities of the named A. macleodii strains and attempted to connect the marked differences with ecology of these bacteria [14]. The ability of $A$. macleodii strains to grow at different temperatures $\left(18,26,37\right.$ and $\left.42{ }^{\circ} \mathrm{C}\right)$ was studied under decompressed conditions to compare their growth rates and morphological features. No strains were able to grow at $42^{\circ} \mathrm{C}$. The surface strains, in contrast to the deep ones, were able to grow at $37^{\circ} \mathrm{C}$. The optimal growth rate was marked at $26^{\circ} \mathrm{C}$ for all strains. We discovered that the cell size of $A$. macleodii strains depended on the depth of their isolation only: the deep strain cells were two times longer than the surface ones.

A finer dissection of the $A$. macleodii genome shows an extremely efficient recruitment of four GI genes present in the island that were all annotated as metal efflux pumps. Metal detoxification seems to be the common motive 
of the gene clusters in GI2, including putative efflux pumps for cobalt, zinc, cadmium, silver or copper. The heavy metal resistance of the 23 strains of A.macleodii present in the laboratory of Universidad Miguel Hernandez [15] was assessed by determining the minimal inhibitory concentration for zinc, mercury and lead. It was shown that most of the deep-water isolates were more resistant.

We have studied other heavy metals ions and did not find any significant distinction between deep and surface isolates sensitivity to those. A. macleodii strains survived at lead ions concentration of 200-400 $\mu \mathrm{g} / \mathrm{ml}$ and copper ions $20-50 \mu \mathrm{g} / \mathrm{ml}$. Sensitivity to cadmium ions substantially varied from strain to strain $(10-200 \mu \mathrm{g} / \mathrm{ml})$.

With the help of fatty acid analysis the deep and surface isolates were clearly separated into two clusters (Fig. 5).

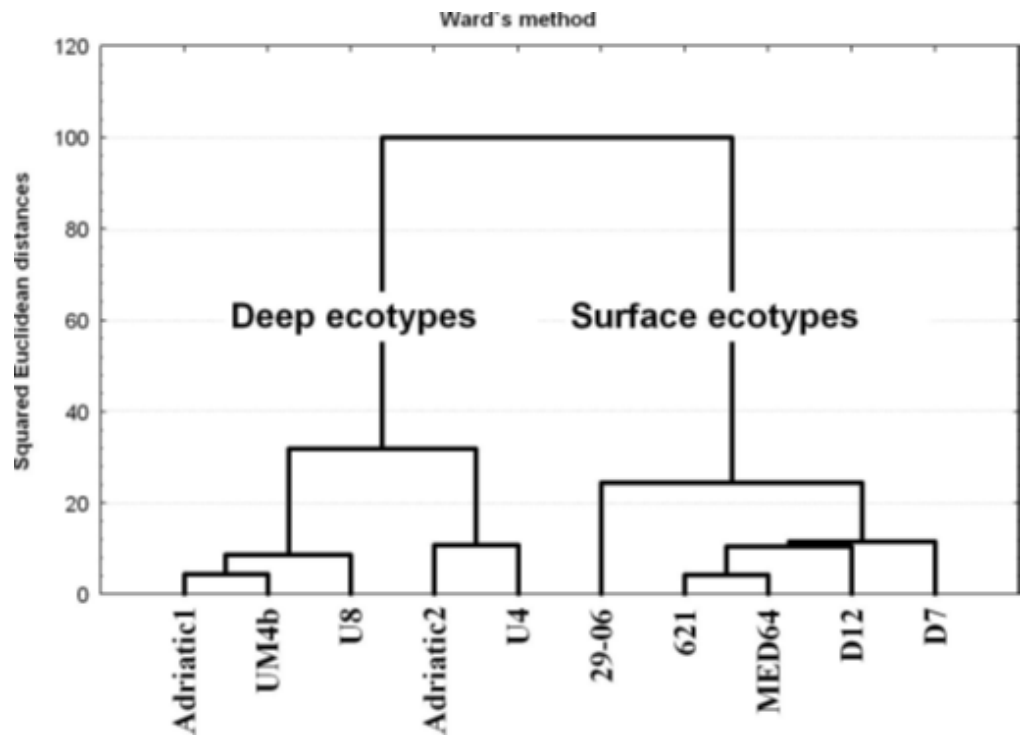

Fig. 5. Dendrogram of $A$. macleodii strains according to their fatty acid profiles

The strains isolated from the deep sea waters contained a 10-15\% larger portion of monounsaturated (C16:1 and $\mathrm{C} 18: 1)$ fatty acids in comparison with the strains isolated from the surface layers of water. This observation may show a relation to the specific conditions of the habitat of the deep sea: low temperature and high pressure.

Restriction analysis of $16 \mathrm{~S}$ rRNA seemed to reveal insufficient genomic variability among $A$. macleodii strains isolated from different econiches: we were able to distinguish one among $10 \mathrm{~A}$. macleodii strains. Our results are consistent with data from other studies that determined heterogeneity of the fragments of this gene among marine organisms, including A. macleodii [5]. We used DNA-markers that are highly polymorphic and allow an evaluation of genome variability to study intraspecies genomic heterogeneity of $\mathrm{A}$. $\mathrm{ma}$ cleodii. Patterns of PCR products obtained by using M13 primer and 3 primers to short nucleotide repeats were scored, explored and compared between the strains (Fig. 6). 


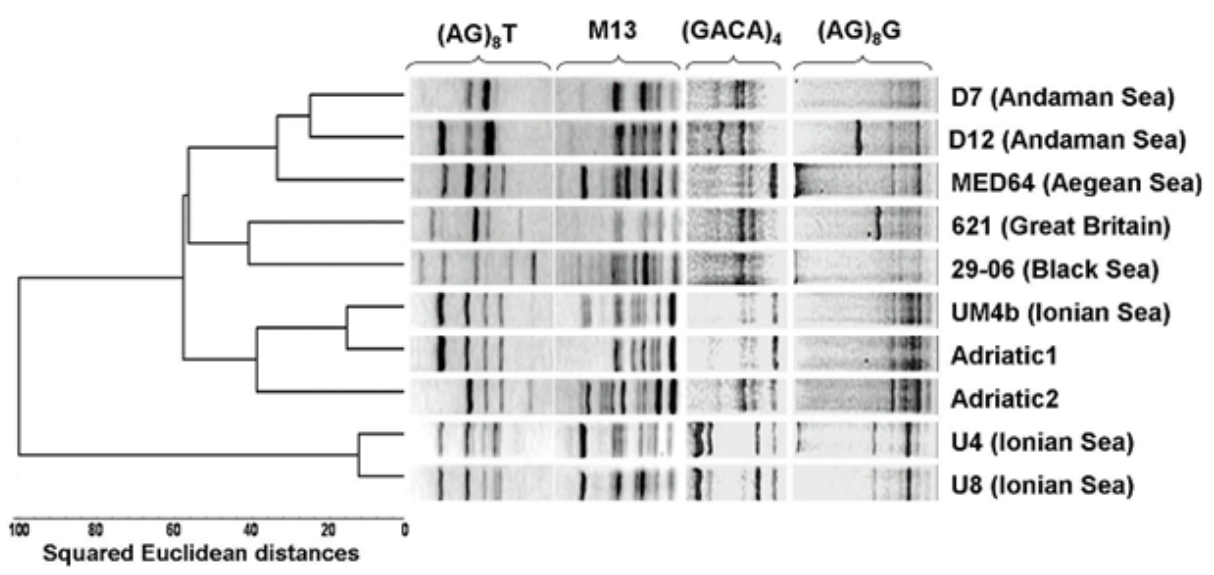

Fig 6. Dendrogram of $A$. macleodii strains according to their amplicon patterns

The level of polymorphic bands was high and amounted to up to $79 \%$. The group of surface strains possessed a higher level of polymorphism in comparison with the group of deep ones (72\% and $62 \%$ respectively) [14].

We observed that different $A$. macleodii strains possessed varied affinity to the tested lectins. Cluster analysis of polysaccharide profiles resulted in separation of the strains into two major groups. One group was composed of the deep water strains (from the 3,500 m); the second was divided into two subclusters: the first subcluster was composed of the strains isolated from the $1,000 \mathrm{~m}$ deep water, the second subcluster included strains isolated solely from surface waters.

In our research, we conducted a comprehensive comparative analysis of two A. macleodii ecotypes and showed the differences in morphology and fatty acid content between the strains inhabiting deep and surface waters. The most significant features were marked, first of all, in the cell size (deep strains were two times longer than strains from surface water), and, second, in the fatty acid composition (strains were readily divided into two separate clusters). Strains were also distinct in their affinity to various lectins, which can be connected to the structural peculiarities of their polysaccharide matrices.

The data obtained in the current research allow concluding that the marked peculiarities mainly reflect specific environmental conditions of depth and surface waters from which the strains were isolated. To a lesser degree, they are related to the geographical area of the bacterial habitat. On the other hand, such considerable differences in ecotypes morphology and physiology allow to assume that probably they are representatives of two subspecies or even two different species of Alteromonas.

The presented data illustrate how analysis of genome structure allows to find areas, which determine certain (sometimes new and unknown) properties of bacteria: the metabolites biosynthesis, the enzymes activity, resistance to chemical agents etc. The presence of such characteristics must be experimentally proved. Only then we may answer the question: what is the metabolic, evolutionary or ecological role of the analyzed properties? This allows to obtain an integral picture of the organization and functioning of a microbial cell. In this article we tried to present one of the approaches to answer these questions. 


\section{В.В. Клочко}

Інститут мікробіології і вірусології ім. Д.К. Заболотного НАН України, вул. Академіка Заболотного, 154, Київ, 03143, Украӥна

\section{ЕКОЛОГІЯ, СИСТЕМАТИКА ТА АНТИБІОТИЧНА АКТИВНІСТЬ PSEUDOMONAS BATUMICI I ALTEROMONAS MACLEODII TA ÏX ЗВ'ЯЗОК ЗІ СТРУКТУРОЮ ГЕНОМІВ}

Резюме

На основі комплексних досліджень структури геному і ряду біологічних ознак отримано нові дані з екології, систематики та синтезу біологічно активних сполук типовим штамом-продуцентом високоефективного антистафілококового антибіотика батуміну Pseudomonas batumici УКМ В-321 і широко розповсюджених у Світовому океані штамів Alteromonas macleodii.

Таксономічним аналізом показано, що P. batumici являє собою новий вид бактерій. Повним сіквенсом геному типового штаму P. batumici УКМ В-321 методом Illumina Hi-Seq встановлено, що ДНК штаму містить 127 контигів загальною довжиною 6608172 п.н. Ідентифіковано оперон біосинтезу батуміну, який складається з 77000 п.н., містить 28 кодуючих генів і має більший Г+Ц вміст ДНК; комп’ютерною програмою SeqWord Genomic Island Sniffer встановлено горизонтальний перенос оперону батуміну. Найбільш філогенетично близькими до P. batumici УКМ В-321 видами виявилися P. gingeri i P. protegens, однак у них був відсутній оперон біосинтезу батуміну. HPLC-аналіз культуральної рідини $P$. batumici УКМ В-321 показав наявність у ній батуміну; в культуральній рідині P. gingeri батумін або його аналоги були відсутніми.

Вивчено фенотипові, хемотаксономічні і генетичні властивості 5 глибоководних морських штамів A. macleodii, ізольованих з глибини 1000-3500 м та 5 штамів, виділених з поверхневих шарів води. Методом електронної мікроскопії встановлено, що глибоководні штами виявилися вдвічі довшими $(2,1 \pm 0,2 \times 0,7 \pm 0,1$ мкм), аніж поверхневі $(1,1 \pm 0,1 \times 0,6 \pm 0,1$ мкм). Аналіз жирнокислотних профілів глибоководних і поверхневих штамів дозволив розділити їх на два кластери. Знайдена різниця у лектинзв'язуючій активності штамів, виділених з різних глибин, свідчила про їх різні за структурою екзополісахаридні матрикси. Аналіз результатів ПЛР з ДНК-маркерами показав більш високий рівень поліморфізму у поверхневих штамів у порівнянні з глибоководними. Знайдені особливості штамів A. macleodii, очевидно, є відображенням специфічних умов існування, в яких вони знаходяться на поверхні або в глибинах Світового океану.

Ключові слова: Pseudomonas batumici, антибіотик батумін, Alteromonas macleodii, систематика, структура геномів.

\section{В.В. Клочко}

Институт микробиологии и вирусологии им. Д.К. Заболотного НАН Украины, ул. Академика Заболотного, 154, Киев, 03143, Украина

\section{ЭКОЛОГИЯ, СИСТЕМАТИКА И АНТИБИОТИЧЕСКАЯ АКТИВНОСТЬ PSEUDOMONAS BATUMICI И ALTEROMONAS MACLEODII И ИХ СВЯЗЬ СО СТРУКТУРОЙ ГЕНОМОВ}

Резюме

На основе комплексных исследований структуры генома и ряда биологических свойств получены новые данные по экологии, систематике и синтезу биологически 
активных соединений типовым штаммом-продуцентом высокоэффективного антистафилококкового антибиотика батумина Pseudomonas batumici УКМ В-321 и широко распространенных в Мировом океане штаммов Alteromonas macleodii.

Таксономическим анализом показано, что $P$. batumici представляет собой новый вид бактерий. Полным сиквенсом генома типового штамма P. batumici УКМ В-321 методом Illumina Hi-Seq установлено, что ДНК штамма содержит 127 контигов общей длиной 6608172 п.н. Идентифицировано оперон биосинтеза батумина, который состоит из 77000 п.н., содержит 28 кодирующих генов и имеет более высокое Г+Ц содержание ДНК; компьютерной программой SeqWord Genomic Island Sniffer установлен горизонтальный перенос оперона батумина. Наиболее филогенетически близкими к P. batumici УКМ В-321 видами являются P. gingeri и P. protegens, однако в них отсутствовал оперон биосинтеза батумина. HPLC-анализ культуральной жидкости P. batumici УКМ В-321 показал наличие в ней батумина; в культуральной жидкости P. gingeri батумин или его аналоги отсутствовали.

Изучены фенотипические, хемотаксономические и генетические свойства 5 глубоководных морских штаммов A. macleodii, изолированных из глубины 1000-3500 м и 5 штаммов, выделенных с поверхностных слоев воды. Методом электронной микроскопии установлено, что глубоководные штаммы оказались вдвое длиннее $(2,1 \pm 0,2 \times 0,7 \pm 0,1$ мкм), чем поверхностные $(1,1 \pm 0,1 \times 0,6 \pm 0,1$ мкм). Анализ жирнокислотных профилей глубоководных и поверхностных штаммов позволил разделить их на два кластера. Выявленные отличия в лектинсвязывающей активности штаммов, выделенных из различных глубин, свидетельствовали о различной структуре их экзополисахаридного матрикса. Анализ результатов ПЦР с ДНК-маркерами показал более высокий уровень полиморфизма у поверхностных штаммов по сравнению с глубоководными. Найденные особенности штаммов A. macleodii, очевидно, являются отражением специфических условий существования, в которых они находятся на поверхности или в глубинах Мирового океана.

Ключевые слова: Pseudomonas batumici, антибиотик батумин, Alteromonas macleo$d i i$, систематика, структура геномов.

1. Bernd H, Rehm A. Pseudomonas: Model Organism, Pathogen, Cell Factory. Verlag GmbH: Wiley-VCH; 2008.

2. Esipov SE, Kiprianova EA. Batumin, a novel antibiotic produced by Pseudomonas batumici. $5^{\text {th }}$ Int. Conf. on Chemical Synthesis of Antibiotics and Related Microbial Products. Hungary: Debrecen; 1996. p. 14.

3. Garcia-Martinez J, Acinas SG, Massana R, Rodriguez-Valera F. Prevalence and microdiversity of Alteromonas macleodii-like microorganisms in different oceanic regions. Environ. Microbiol. 2002; 4: 4250.

4. Ivars-Martinez E, D'Auria G, Rodrigues-Valera F, Sanches-Porro C, Ventosa, A, Joint I, et al. Biogeography of the ubiguitous marine bacterium Alteromonas macleodii determined by multilocus sequence analysis. Mol. Ecol. 2008; 17: 4092-4106.

5. Ivars-Martinez E, Martin-Cuadrado A, D'Auria G, Mira A, Ferriera S, Johnson J, et al. Comparative genomics of two ecotypes of the marine planktonic copiotroph Alteromonas macleodii suggests alternative lifestyles associated with different kinds of particulate organic matter. ISME J. 2008; 2: 1194-1212.

6. Kim JY, Klochko VV, Zelena LB, Kiprianova EA, Avdeeva LV, Reva ON. Analysis of the complete genome sequence of batumin producing strain Pseudomonas batumici 
UCMB-321 revealed that the whole batumin synthesis encoding operon was acquired by horizontal gene transfer. III International Conference on Antimicrobial Research. Spain: Madrid; 2014. p. 150.

7. Kim JY, Klochko VV, Zhuravel EV, Soldatkina MA, Reva ON. Similarity and difference in mechanisms of action of antistaphylococcal antibiotics mupirocin and batumin revealed by in-silico molecular docking . Drug discovery and Therapy World Congress. USA: Boston; 2015. p. 105.

8. Kiprianova EA, Klochko $V V$. [Analysis of the relation between structure and the antibiotic activity of batumin]. Mikrobiol Z. 2009; 71(1): 28-33. Russian.

9. Kiprianova EA, Klochko VV, Zelena LB, Churkina LN, Avdeeva LV. Pseudomonas batumici sp.nov., the antibiotic-producing bacteria isolated from soil of the Caucasus Black Sea coast. Mikrobiol Z. 2011; 73( 5): 3-8.

10. Klochko VV. Biosynthesis and properties of antibiotic batumin. Biotechnologia Acta. 2014; 7(6): 46-50.

11. Klochko VV. [Comparative taxonomic analysis of Pseudomonas batumici and evolutionally related species]. Dopovidi NASU. 2015; 2: 152-157. Russian.

12. Klochko VV, Kiprianova EA, Churkina LN, Avdeeva LV. [Antimicrobial spectrum of antibiotic batumin]. Mikrobiol Z. 2008; 70( 5): 41-46. Russian.

13. Klochko VV, Zelena LB, Kim JY, Avdeeva LV, Reva ON. Prospects of a new antistaphylococcal drug batumin revealed by molecular docking and analysis of the complete genome sequence of the batumin-producer Pseudomonas batumici UCM B-321. Int. J. of Antimicrobial Agents. 2016; 47: 56-61.

14. Klochko VV, Zelena LB, Voychuk SI, Ostapchuk AN. Peculiarities of Alteromonas macleodii strains reflects their deep/surface habitation rather than geographical distribution. J. Gen. Appl. Microbiol, 2012; 58: 129-135.

15.Lopez-Lopez AS, Stal BL, Onishchenko O, Rodriguez-Valera F. Genetic analysis of housekeeping genes reveals a deep-sea ecotype of Alteromonas macleodii in the Mediterranean Sea. Environ. Microbiol. 2005; 7: 649-659.

16. Smirnov VV, Churkina LN, Kiprianova EA. Antibiotic batumin for diagnostics of staphylococci and treatment of Staphylococcus aureus nasal carriage. $10^{\text {th }}$ International symposium on staphylococci and staphilococcal infections. Japan: Tsukuba; 2002. p. 130.

Отримано 08.08.2016 